\title{
The Legal Protection of Indonesian Female Seafarer
}

\author{
Meti Kendek $^{1}$, Hadi Setiawan ${ }^{1}$, Subehana Rachman ${ }^{1}$, Adi Suriadi ${ }^{2}$ \\ ${ }^{1}$ Politeknik Ilmu Pelayaran Makassar \\ ${ }^{2}$ Universitas Islam Makassar \\ Jl. Salodong No.1 Kel Untia Kec. Biringkanaya Makassar \\ e-mail:metikendek22@gmail.com
}

\begin{abstract}
Analysis of legal protection for Indonesian female seafarer. Based on these central issues, this study aims to determine what regulations protect Indonesian female seafarers and how to implement Indonesian female seafarer's protection based on existing ordinances.

The method of data collection was a literature study, observation sheet, and interviews guide. The collected data were analyzed using qualitative descriptive analysis techniques. This study's population was representatives of the Directorate General of Sea Transportation and members of the Indonesian Women Seafarers' Organization, namely: Indonesia Female Marine (IFMA) and Indonesian Lady Seafarers (ILS). The research results showed that national and international law had guaranteed legal protection to Indonesian female mariner of various rules and regulations. This guarantee was used in obtaining decent and productive work into independent, equal, and safe conditions with dignity so that if they do not get discriminatory treatment. Implementation of legal protection for women seafarers has not been accommodated by legal subjects, both in the legal structure, legal substance or legal culture.It is based on conditions where there are still minimum opportunities for decent work and lack of social protection for female seafarer when doing their job. This is evidenced by the Circular Letter of the DirectorGeneral of Hubla of the Ministry of Transportation No.Um.003 / 80/9 / DJPL-1 concerning the Fulfillment / Granting of the Rights of Female Seafarer, and the Circular of the Ministry of Transportation's Directorate General of Transportation Hubla No.UM.002 / 89/3 / DK -17 concerning the Fulfillment / Granting of the Rights of Female Seafarer, which was philosophically issued at the insistence of the Indonesian Female Marine (IFMA) which received many reports from the female seafarer.
\end{abstract}

Keywords: Seafarer, Female, Legal Protection

\section{Introduction}

Both juridically, at the international and national levels, Indonesian laws and regulations state the principle of equal rights between men and women. However, at the level of implementation of state administration, there are nationality and injustice against women. Women are always left behind and marginalized in the fields of economy, education, health, work, and politics. One of the reasons is the patriarchal culture that has developed in Indonesian indigenous peoples. In a society with a patriarchal culture, men are more involved in holding power, which can automatically degrade women's role and existence (Nalom Kurniawan, 2011: 172). 
Indonesia is one of the countries with the highest number of the female mariner in the world. The growth in the number of Indonesian female seafarers is currently growing rapidly. In fact, many shipping companies refuse or do covert discrimination against female mariner for technical reasons that do not make sense. The existence of a female mariner has two legal frameworks that should be obeyed by national shipping companies. Those are the Circular of the Director-General of Hubla of the Ministry of Transportation No: Um.003 / 80/9 / DJPL-1 concerning the Fulfillment / Granting of Women's Rights Seafarers, and the Circular of the Ministry of Transportation's Directorate General of Transportation Hubla No. UM.002 / 89/3 / DK-17 concerning the Fulfillment / Granting of the Rights of Female Mariner.

The moment to commemorate Kartini's Day on April 21, 2019 is a reflection of the struggle of women to get the same freedom and equality as male sailors. Not only career women who work in offices, female mariner in Indonesia also continue to struggle the same rights in working for a living. Chairperson of the Indonesia Female Marine (IFMA) was Capten Suarniati said that most of the women seafarers are still discriminated against in their career. When applying for a job application, this application only reaches a security post. It meant that the application did not forward to shipping management. Even though we received the same education as a male sailor, this was revealed when launching the first female mariner ship in Indonesia at the port of Cirebon. He also said that the capabilities of the female mariner in Indonesia are many and varied. The ability of female mariner in Indonesia exceeds than male seafarers. Thus, currently doing our best in existing programs to equalize gender and seek an MOU with shipping companies in Indonesia. Talking about female mariner, maybe many people do not know that the growth in the number of Indonesian female mariner is getting bigger, public interest in shipping education, and becoming seafarers is increasing, including women. As of 15 August 2017, the number of female mariner in various positions and diploma levels, active and nonactive sailing were 8,141 seafarers. (DG Hubla data base, 2017).

\section{Methodology}

This research was conducted in the relating to government agencies such as the Directorate General of Sea Transportation in Jakarta. This place was the entry point for reports by women seafarers 'organizations as well as representative offices for national shipping, and women seafarers' organizations such as the Indonesian Lady Seafarers (ILS) secretariat. As for library materials, researchers will search for various online reading sources in the form of websites, e-books, and other media and offline media in the form of University Library books with statutory analysis.

This research population was representatives of the Directorate General of Sea Transportation and members of the Indonesian Women Seafarers' Organization, namely: Indonesia Female Marine (IFMA) and Indonesian Lady Seafarers (ILS).

This research sample was the females' seafarer, who was considered to represent all population elements. As well as the parties involved in the Circular of the Director General of Hubla of the Ministry of Transportation No: Um.003 / 80/9 / DJPL-1 concerning the Fulfillment / Granting of the Rights of Women Seafarers, and the Circular of the Ministry of Transportation's Directorate General of Transportation Hubla No. UM.002 / 89/3 / DK-17 concerning the Fulfillment / Granting of Women Seafarers' Rights, such as DGT and related women seafarers organizations and shipping agencies. 
This type of research is Normative qualitative research. Types of research and data collected in a study, so the data analysis technique used was normative qualitative analysis. The approach method used in this research was normative/doctrinal juridical.

\section{Results and Discussion}

\subsection{The Results}

In fact, the currently available legal regulations have not been able to regulate the rights of women seafarers comprehensively, either through favorable laws regulating employment (through Law of the Republic of Indonesia Number 13 of 2003 concerning Manpower and implementing laws and regulations under it) and shipping (through Law of the Republic of Indonesia Number 17 of 2008 concerning Shipping along with enforcing laws and regulations under it, namely Government Regulation Number 7 of 2000 concerning Maritime Affairs). Therefore an instrument is needed that regulates legal protection for Indonesian women seafarers and its implementation in law enforcement so that the rights of Indonesian women seafarers are guaranteed.

The rights of women seafarers in question are the rights to get career opportunities or job opportunities, the right to be adequately treated at work, and the right to get preventive and repressive legal protection, which all become a fundamental human right or Human Rights (HAM). Although based on researchers' findings specifically, all the rights relevant to female seafarers have not explicitly been regulated by law or other government policies, the basis for legal protection to treat female seafarers is the same without discrimination differences with male seafarers. And held in several national and international legal instruments as well as following government policies or related agencies in enforcing these legal protections.

Legal protection for citizens' rights in a place is a must because it is an integral part of human rights, which is regulated in the constitution and international human rights instruments ratified by the Government. As a concept, human rights have a comprehensive meaning, considering that human rights issues are universal, do not recognize boundaries: the territory of the State, politics, economy, society, culture, and law does not acknowledge even gender. As a gift, human rights are a fundamental right given by Almighty God to humankind without questioning differences in social, cultural, political, and economic backgrounds.

According to Soedikno Mertokusemo that:

Legal subjects as bearers of rights and obligations (de dragger Van do rechhten en Plichten), be they human (naturlijkepersoon) legal entities (rechtspersoon) or position (ambt), can take legal actions based on ability (bekwaamheid) or the authority (bevogdheid) it has.

In social interactions in the community, many legal relationships arise due to legal actions and legal subjects. This legal action is the beginning of the birth of a legal relationship (rechtsbetreekking) having legal consequences. For the legal relationship between legal issues to run in harmony, balance, and fairness in the sense that each legal issue gets his right and carries out his obligations imposed on him, the law appears as a rule of the game in regulating the legal relationship. Law was created as a means or instrument to regulate the rights and obligations of legal subjects.

Besides, law also functions as an instrument of protection for legal subjects-law functions as a protection for human interests. For social interests to be protected, the law must be implemented. Law enforcement can take place naturally, peacefully, but it can also occur because of lawlessness. Violation of law occurs when a particular legal subject 
does not carry out the obligations that should be carried out or because it violates another legal subject's rights. Legal issues whose rights are violated must get legal protection. "

Legal protection for the people is a universal concept, in the sense that every country that puts forward itself as the rule of law, including one of which is legal protection which is entirely indistinguishable between men and women, this is better known as Equality before the Law (Equality before the Law). However, as Paulus Lotulung, each country has its ways and mechanisms to realize legal protection and the extent to which legal protection is provided.

Furthermore, Paulus Lotulung stated:

"Knowing the fields of legal protection, it is also necessary to mention the kinds of government actions that allow harm to the community and for individuals or private legal entities. In general, there are three kinds of government actions, namely government actions in making laws and regulations (regeling), the Government's actions in issuing decrees (materiele daad). The first two fields occur in the public sector and are subject to and regulated under public law. The latter is precisely in the civil industry and, therefore subject to and regulated under civil law.

From the various definitions and definitions of legal protection above, several regulations are concerned with women seafarers' legal safety in general and specifically through national and international legal instruments, which become the basis for Indonesian women seafarers' legal protection.

Protection for citizens against government action. According to Phipus M. Hadjon, there are two legal protections, namely:

"Preventive and repressive legal protection. In preventive legal protection, the people can submit objections (Insprak) or opinions before a government decision takes a definitive form.

This means that preventive legal protection aims to prevent disputes. In contrast, on the other hand, repressive legal protection is very significant for government actions based on freedom of movement. With the existence of repressive legal protection, the Government is motivated to be careful in making decisions based on discretion.

Based on the results of the research, the legal instruments that discuss the protection of the rights of women seafarers based on legal protection for those concerned are regulated in: Article 27, Article 28, Article 29 and Article 31 of the 1945 Constitution in granting Human Rights, Article 2 Law of the Republic of Indonesia Number 39 of 1999 concerning Human Rights also regulates that the State of the Republic of Indonesia recognizes and upholds Human Rights and fundamental human freedoms as rights that are inherently inherent and inseparable from humans that must be protected, respected and upheld for the sake of enhancement of human dignity, welfare, happiness, and intelligence and justice, the ILO Maritime Labor Convention 2006 (Maritime Labor Convention) in Law No. 15 of 2016 concerning Ratification of the Maritime Labor Convention which aims to strengthen the protection of Indonesian seafarers and crew members, and Law Number 21 of 1999 concerning Ratification of the ILO Convention No. 111 concerning Discrimination in Respect of Employment and Occupation (ILO Conventions on Discrimination in Employment and Occupation). All regulation about seafarer answered that the implementation of Law Protection to female seafarer in Legal Substance that base on Regulation woman have equality as seafarer with other seafarer. And about the legal structure and legal culture, all law enforcement agencies together with relevant agencies such as Directorate General of Sea Transportation and all women seafaring organizations

This paper is presented in The $4^{\text {th }}$ International Conference on Maritime Education and Training 205 
are legal structures that can supervise law enforcement in this case to protect female sailors in order to obtain their rights both in their work and fundamental rights in them. And will be supporting by legal culture member of law enforcement from the government and member of institution.

\subsection{Discussion}

Based on the research results through interviews and direct observation, there are several reasons why female seafarers still receive legal protection in terms of getting a job on a ship. The Ministry of Transportation responded to discrimination against female seafarers by staffing agencies and shipping companies in Indonesia. Based on this report, the Ministry of Transportation made a circular and instructed shipping company in Indonesia regarding the recruitment and fulfillment of marine workers' rights, namely prohibiting manning agencies and Indonesian shipping companies from implementing gender discrimination policies, including recruiting female crewmembers and written or unwritten. The prohibition on gender discrimination policy applies at all stages of the maritime profession, namely from the process of marine practice, recruitment, carrying out work as a seafarer, and terminating as a seafarer.

Violation of gender discrimination prohibition will result in removing, among others; SIUPPAK, SIUPAL, and SIOPSUS. Based on this circular, crewing agency operators or ship owners are prohibited from discriminating against female seafarers. If this practice is carried out, the permit that has been obtained will be revoked.

From the interviews we have conducted with IFMA (Indonesian Female Mariner) administrators, the Government has not fully guaranteed the implementation of legal protection for a woman seaman's basic rights, namely the right to work on ships. There are still many shipping companies that refuse to accept female seafarers for various reasons. This is based on many complaints submitted to the IFMA organization that they were still rejected when They applied to shipping companies. Among the rejections they receive, sometimes it doesn't make sense just because of the bad behavior of female seafarers who have worked in their ships, then generalize all-female seafarers.

To do the interviews with ILS (Indonesian Lady Seafarers), They said that Indonesian women who take part in the shipping industry still often experience stigma, ranging from being considered weak to vulnerable to sexual harassment. But Indonesian Lady Seafarers (ILS) wants to change that. The organization, which now brings together around 200 women seafarers in Indonesia, voices that there are increasingly limited opportunities to have a career in this industry. The impact of the global economic crisis has caused industrial growth to erode. As a result, opportunities for women seafarers are also increasingly limited.

The ILS Asia coordinator, Yudha Ermerra, confirmed this. "Now, the opportunity for women to become sailors on board is still difficult," he said.

"Being able to join a ship is already lucky, let alone a career as a skipper. The lesser jobs at sea are also due to the decline in world oil prices and mining goods/coal. In this situation, companies prefer male seafarers to female seamen.

Moreover, there is a stigma against women seafaring in Indonesia. Many companies close their doors because they think that women's careers on voyages are short, at most 5 years. After that, he got married and didn't sail anymore. Another factor is comfort because the company does not want to deal with sexual harassment reports among its workers on board.

This paper is presented in The $4^{\text {th }}$ International Conference on Maritime Education and Training 
On average, companies think that women are weak, spoiled, hard to rely on for jobs on boats, hard work, and require people to be alert. Female seafarers want to prove that they can work and excel at the same level as male seafarers. Female seafarers can do the same job as men, such as work not only navigating ships but also painting, pulling ropes, removing rust, and others.

An interview with the Directorate General of Sea Transportation give the conclusion that his party had accommodated women seafarers' interests and needs by issuing a circular. However, the reality is that what they have published as a circular is merely appealing to shipping companies to provide opportunities to work for female seamen on board. The Directorate General of Sea Transportation has not supervised or monitored shipping companies. This also occurs because there are no complaints from female seafarers to the Directorate General of Sea Transportation which are rejected by shipping companies.

The implementation of Law Protection to female seafarer's are influenced by three parts of Legal substance, legal structure, and legal culture. There are many regulations that rule and protect equality before the law between male and female seafarer, and all others regulation. That regulation was implemented by doing from Indonesian Lady Seafarer (ILS) and Indonesian Female Mariner (IFMA) report violation to the Directorate General of Sea Transportation and to law enforcement to be followed up with the legal culture.

\section{Conclusion}

National law and international law have guaranteed legal protection to Indonesian women seafarers from various laws and regulations in obtaining decent and productive work in independent, equal, safe, and with dignity so that they are not subject to discrimination. Implementation of legal protection for women seafarers has not been accommodated by legal subjects, either in the legal structure, legal substance, or legal culture. It is based on conditions where there is still a lack of decent work opportunities and less social protection for women seafarers when doing their work.

The Indonesian Government is expected to make regulations that are binding to provide legal protection for women seafarers aimed at all shipping company agencies, both Government and private, that can empower women as seafarers safely and adequately.

Besides, Directorate General of Sea Transportation is expected to pay special attention to the legal structure to monitor the regulation of legal protection for women seafarers and basic understanding for the community, especially shipping companies, so that all legal instruments can be implemented properly.

\section{References}

[1] Abdullah Marlang, 1997, Law Enforcement in the Field of Conservation of Living Natural Resources and Their Ecosystems in South Sulawesi, Dissertation of Hasanuddin University Postgraduate Program, Makassar.

[2] Achmad Ali, 2011, Unveiling the Veil of Law, Revision, Ghalia Indonesia, Bogor

[3] Andi Hamzah, 1994, Principles of Criminal Law, Rineka Cipta, Jakarta

[4] Ani Widyani Soetjipto, 2005, Women's Politics is not an Eclipse, kompas, Jakarta

[5] Friedrich Julius Stahl, dalam Muh. Tahir Ashary, 1992, State law, Bulan Bintang, Jakarta

[6] M. Syukri Akub, 2012 Due Process of Law Insights into the Criminal Justice System, First Edition, Mahakarya Rangkang, Yogyakarta 
[7] Nalom Kurniawan, 2011, Women's Human Rights from a legal and religious perspective, Jurnal Konstitusi, Vol.IV, No. 1

[8] Paulus Effendi Lotulung, 2013, State Administration Law and Power, Salemba Humanika, Jakarta

[9] Peter Baehr, et.al. (ed.), 1997, Instrument of International in Basic Human Rights, Yayasan Obor Indonesia, Jakarta

[10] Philipus M. Hadjon, 1983, Protection for the People in Indonesia, Bina Ilmu, Surabaya

[11] Setiono, 2007, Legal And Law Enforcement, Universitas Sebelas Maret, Surakarta

[12] Soerjono Soekanto, 2002, Introduction to Legal Research, UI Press, Jakarta 